\title{
An updated systematic review and meta- analysis of the prevalence of hepatitis $B$ virus in Ethiopia
}

\author{
Teshiwal Deress Yazie* (D) and Mekonnen Girma Tebeje(D)
}

\begin{abstract}
Background: Hepatitis B virus is one of the major public health concerns globally. It is highly infectious and can be transmitted from person to person through vertically or horizontally via contaminated body fluids. Despite the provision of an effective vaccine, it remains a major problem worldwide, particularly among the developing countries.

Methods: Online electronic databases including PubMed, Google Scholar, Science Direct, African Index Medicus, African Journals Online, and WHO Afro Library were searched and published articles from 2010 to June 8, 2019, were considered. Both authors independently screened articles and extracted the data. Funnel-Plots and Egger's test statistics were used to determine the presence of small-study effects and publication bias. The pooled prevalence of HBV was analyzed using the random-effects model. The possible sources of heterogeneity was analyzed through subgroup analysis, sensitivity analysis, and meta-regression.
\end{abstract}

Results: The overall pooled prevalence of HBV was $6 \%$ and among subgroups, pregnant women, healthcare workers, and HIV positive patients accounted for $5 \%$ for each group. Relatively low prevalence (4\%) was obtained among blood donors. The Egger's test statistics ( $p=0.747$ ) indicated the absence of publication bias. In addition, from the sensitivity analysis, there was no influence on the overall effect estimate while removing a single study at a time. The level of heterogeneity was reduced among pregnant women, HIV positive and studies with unknown sampling techniques. After conducting meta-regression, province, study group, screening method, and quality of papers were identified as sources of heterogeneity.

Conclusions: The overall pooled prevalence of HBV in Ethiopia was high. Strengthening and scaling up of the scope of the existing vaccination program and implementing novel approaches including screen-and-treat could be implemented to reduce the burden of the disease. Generally, the study can provide current prevalence estimate of HBV that could vital for intervention to tackle the disease.

Keywords: Hepatitis B virus, Viral hepatitis, Pooled prevalence, Meta-analysis, Ethiopia

\section{Background}

Hepatitis B virus (HBV) is a major global public health problem [1]. The virus is highly infectious and can be transmitted through mother to child or via contaminated body fluid exposure such as unprotected sex, contaminated medical equipment, and blood donation $[2,3]$. Despite the provision of an effective vaccine, it remains

\footnotetext{
*Correspondence: teshiwalderess@gmail.com; teshiwal.deress@uog.edu.et Unit of Quality Assurance and Laboratory Management, School of Biomedical and Laboratory Sciences, College of Medicine and Health Sciences, University of Gondar, P.O. Box 196, Gondar, Ethiopia
}

the main public health concern particularly among developing countries [4]. Hepatitis B virus infection can be determined by diagnosing the presence of hepatitis $B$ surface antibody (HBsAb), hepatitis $B$ pre-core antigen (HBeAg), hepatitis B pre-core antibody (HBeAb), hepatitis B surface antigen (HBsAg), or hepatitis B core antibody ( $\mathrm{HBcAb})$ sero-marker reactivity [5]. The presence of HBsAg represents active acute or chronic infections; whereas, the $\mathrm{HBeAg}$ indicates high viral replication while $\mathrm{HBsAb}$ and $\mathrm{HBeAb}$ are indications of HBV resolution [6].

(C) The Author(s). 2019 Open Access This article is distributed under the terms of the Creative Commons Attribution 4.0 International License (http://creativecommons.org/licenses/by/4.0/), which permits unrestricted use, distribution, and reproduction in any medium, provided you give appropriate credit to the original author(s) and the source, provide a link to the Creative Commons license, and indicate if changes were made. The Creative Commons Public Domain Dedication waiver (http://creativecommons.org/publicdomain/zero/1.0/) applies to the data made available in this article, unless otherwise stated. 
In Africa, about 15 to $60 \%$ of the population is positive for at least one of the mentioned serological markers [7].

Hepatitis B virus is a life-threatening infection which attacks liver cells and can cause acute and chronic disease [8]. The acute HBV infection is usually a selflimiting disease [9]; however, chronic infection can cause liver cancer that becomes the second most common causes of death among cancer disease globally [10]. Annually more than 686,000 people die related to HBV infection complications, including hepatocellular carcinoma and liver cirrhosis [11]. Though HBV vaccination is the most important prevention mechanism [12], it is less likely accessible for private access due to the high cost of the vaccine [13].

Viral hepatitis causes high mortality and disability which is classified under the top 10 killer diseases [14]. About 2 billion people are infected with HBV globally from which over 240 million are chronically infected and are at high risk of developing liver cirrhosis and hepatocellular carcinoma [15]. According to the global burden of disease, an estimated 786,000 people die annually due to HBV infections from which 17, 43, and $40 \%$ were caused by acute infections, liver cancer, and cirrhosis, respectively [16]. The global prevalence of $\mathrm{HBV}$ infection is highly heterogeneous, and the highest prevalence (6.2 and 6.1\%) is among the WHO Western Pacific and WHO African regions, respectively. As a part of the sub-Saharan region, Ethiopia is ranked medium to high endemicity for HBV infection [17]. Hepatitis B virus screening and case management are costly. In a highprevalence area, HBV screening and treatment costs accounted for $\$ 29,230$ per quality adjusted life-year [18]. Hepatitis B virus infection is also a major problem in Ethiopia with its prevalence vary from region to region even it is heterogeneous among studies within a region. The first systematic review and meta-analysis of viral infections in Ethiopia was conducted in 2016 [19]; however, the study included with $60 \%$ of old articles published before 2010. Due to this, it is difficult to estimate the current pooled prevalence estimate. In addition, as the study was conducted on more than one viral infections it lacked the detailed analysis of the HBV. Currently the Ethiopian government has given an emphasis to reduce the burden of $\mathrm{HBV}$. Therefore, establishing the latest statistics regarding HBV pooled prevalence in Ethiopia could be vital in designing and implementing intervention programs and guidelines to reduce this national and international public health issue.

\section{Methods}

\section{Study setting}

This review was conducted in Ethiopia which is found in the Horn of Africa. Ethiopia is a highly populated developing country with a total population expected to be more than 100 million people within $1,100,000 \mathrm{~km}^{2}$ landmass. The country is divided into nine administrative regions and two self-administrative cities. Recent studies indicated that HBV genotype A, D, C, E, and G are common in Ethiopia [20, 21]. The Federal Ministry of Health $(\mathrm{FMoH})$ has established and implemented different strategic plans to reduce the burden of $\mathrm{HBV}$ in the country including the provision of selective vaccination programs for those high-risk groups such as health professionals, and those working in close contact with the local population and routine screening of patients suspected of viral hepatitis.

\section{Study design and protocol registration}

The protocol of this systematic review and meta-analysis was designed according to the Preferred Reporting Items for Systematic Reviews and Meta-Analysis Protocols (PRISMA-P 2015) Guidelines [22]. The protocol was registered in the PROSPERO database with the protocol registration number of CRD42019131382.

\section{Article searching strategy}

First, the PROSPERO database and database of abstracts of reviews of effects (DARE) (http://www.library.UCSF. $\mathrm{edu}$ ) were searched to check whether published or ongoing projects exists related to the topic. The literature search strategy, selection of studies, data extraction, and result reporting were done in accordance with the Preferred Reporting Items for Systematic Reviews and Meta-Analyses (PRISMA) guidelines [23]. A comprehensive literature search was done in PubMed, Google Scholar, Science Direct, African Index Medicus, African Journals Online (AJOL), and WHO Afro Library Databases using keywords and Boolean operators (AND and OR) combination. The keywords used to search the mentioned databases were "hepatitis B virus", "HBV", "hepatitis B surface antigen", "HBsAg", "viral liver disease", "viral hepatitis", "prevalence", "seroprevalence", "seroepidemiology", "magnitude", "Ethiopia”, "year". According to the databases' requirement, the search string was customized for each database. As an example the PubMed search string of this review is attached as an additional file (Additional file 1). In addition, Google hand searching and screening of reference lists of the included and excluded studies were done. All full-text articles, published from 2010 to 2019, were considered and the last search was done on June 8, 2019.

\section{Eligibility criteria}

Studies were eligible only if they were primary study fulltext articles, published in peer-reviewed journals from 2010 to 2019, in English, and from the Ethiopian settings. In addition, articles which reported the magnitude of HBV prevalence were included. Studies conducted using 
valid HBV screening test methods, with clearly stated prevalence data or if missed the presence of sufficient data to calculate the prevalence were also considered as an inclusion criteria. Regarding the exclusion criteria, studies with unclear prevalence or methodological errors were not included in the study.

\section{Article selection and extraction}

All the searched articles were imported into EndNote version X9 software and duplicate articles were removed. Then both authors screened articles independently to identify eligible studies according to the inclusion criteria. The data abstraction form was prepared in Microsoft Excel sheet which includes; the name of the first author, year of publication, year of study, setting (urban or rural), region, screening method (Enzyme-Linked Immunosorbent Assay (ELISA), rapid diagnostic tests (RDT), immunoassay (IA) or not mentioned), study group, sampling technique, sample size, study design, and number of $\mathrm{HBV}$ positive cases. Both authors extracted data files from the full-text articles independently. Any disagreement between the data extractors was resolved by consensus.

\section{Quality assessment}

Both authors critically apprised the included studies independently using the Joanna Briggs Institute (JBI) quality assessment tool for prevalence studies [24]. The critical appraisal tool included nine parameters which have yes, no, unclear and not applicable options; 1) appropriate sampling frame, 2) proper sampling technique, 3) adequate sample size, 4) study subject and setting description, 5) sufficient data analysis, 6) use of valid methods for the identified conditions, 7) valid measurement for all participants, 8) using appropriate statistical analysis, and 9) adequate response rate. Operationally, a score of 1 was assigned for the yes response; whereas 0 scores was provided for no and unclear responses. Finally, the mean score was computed for each article. Then studies with below the mean score and "mean score and above" were categorized as poor and good quality, respectively [24]. The inter-rater agreement between the two data extractors was evaluated using Cohen's Kappa. The result indicated that the inter-rater reliability coefficient (Kappa value) was $0.827(P<0.001)$ which is an indicator of excellent agreement.

\section{Data synthesis and analysis}

Data were analyzed using metaprop program of STATA 15.1 software. When there is across study heterogeneity, the use of random-effects models is recommended [25]. In this case, the DerSimonian and Laird method is the most commonly used approach in meta-analysis [26]. The

$I^{2}$ test statistics was used to check the presence of observed difference between-studies due to heterogeneity. Its value can range from 0 to $100 \%$ and the 75,50 , and $25 \%$ which represent the high, medium, and low heterogeneity among studies, respectively [27]. In addition, a $P$ value of $<0.05$ was also used to the heterogeneity [28]. In this meta-analysis, the $I^{2}$ value was high (97.77\%) which is $>75 \%$ an indication of significant heterogeneity. Due to this reason, the analysis was conducted using a randomeffects model at 95\% CI as opposed to the fixed effects model to adjust the observed variability among studies. The sources of heterogeneity were analyzed using the sensitivity analysis, subgroup analysis, and meta-regression. Funnel plots and Egger's test statistics were used to investigate publication bias and small-study effects. Data manipulation and analysis were done using STATA version 15.1 software (Stata Corp. LLC). College Station, Texas 77,845 USA for Windows.

\section{Results \\ Study selection}

Initially, a total of 2729 studies were identified from the databases and manual searching. From this, 1310 of the studies were removed due to duplication. The remaining 1419 articles were screened by their title and abstract and 1312 of the studies were excluded. Further, 107 fulltext articles were refined and 47 of them were excluded due to being unrelated to the current study, studies on immigrants, review articles, studies conducted before 2010, and studies on immunization. Finally, a total of 60 [20, 29-87] studies were fulfilled the inclusion criteria and enrolled in the study [Fig. 1].

\section{Characteristics of included studies}

A total of 60 articles were included in this systematic review and meta-analysis, with an overall sample size of 106,125 that conducted on the prevalence of HBV in Ethiopia. All the included studies were cross-sectional study designs and the most recent was conducted in 2019. Regarding regional coverage of HBV prevalence studies, more than half of the studies were obtained from Amhara region 22 (36.7\%) [20, 29, 31, 36-38, 44, $46,49,50,53,58,62,63,67-69,71,75,78,79,82]$, Oromia region $12(20 \%)[32,34,41,47,48,56,60,61,64,83$, 85, 87], and Southern Nations, Nationalities and Peoples Region (SNNPR) 9(15\%) [30, 43, 52, 65, 66, 70, 74, 76, 86]. The sample size across the studies was ranged from 108 [53] to 35,435 [44] obtained from the Amhara region. In addition, the qualities of each of the included studies was evaluated using the nine items risk of bias assessment tool (Table 1).

\section{Prevalence of HBV in Ethiopia}

There was a wide HBV prevalence variation among included studies which is ranged from 1\% in Amhara 


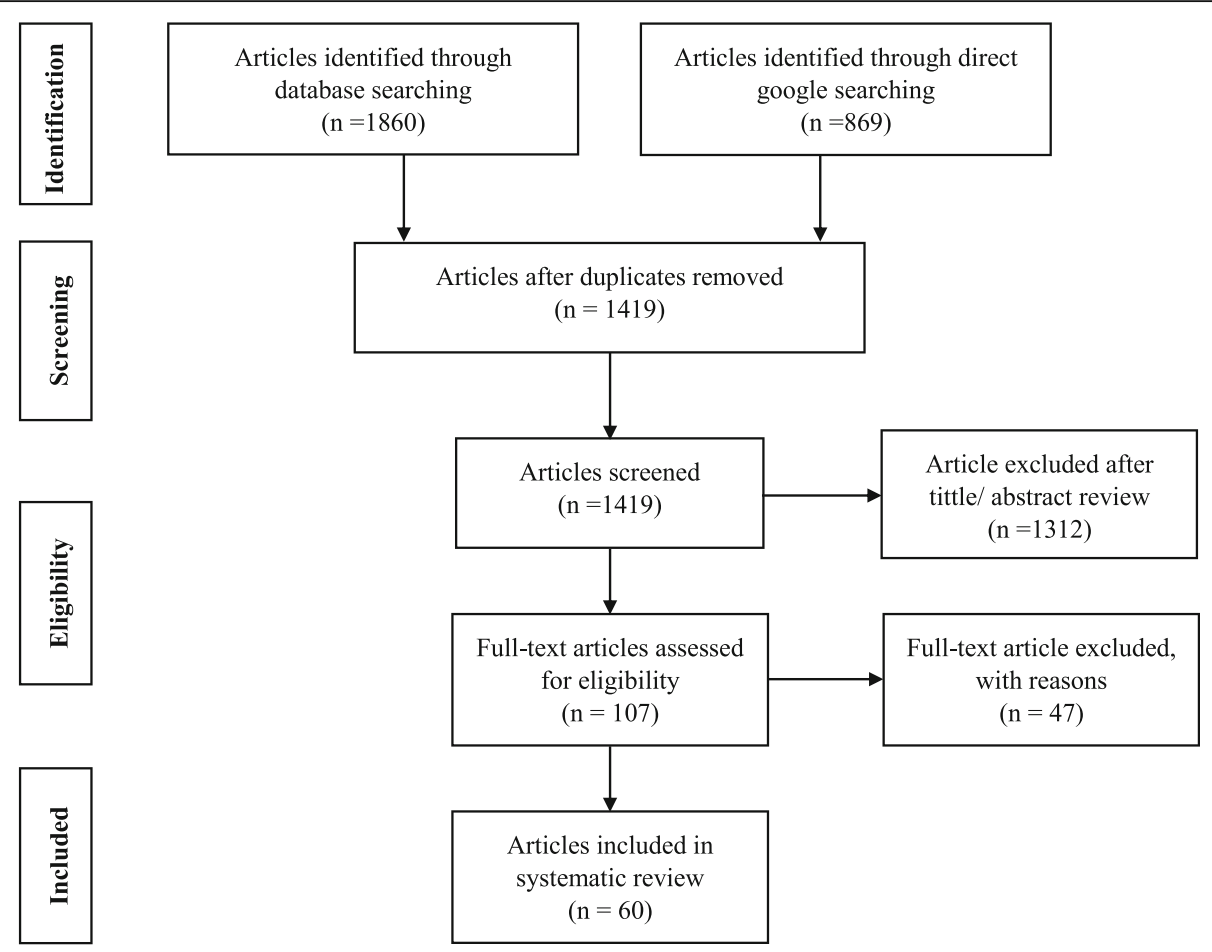

Fig. 1 PRISA flow diagram for identification and selection of articles for inclusion in the review

region to $36 \%$ in Addis Ababa city. Based on the random-effects model, the overall pooled prevalence among 106,125 was $6 \%$ (95\% CI: 5 to $6 \%$ ) with heterogeneity index $\left(\mathrm{I}^{2}\right)$ of $97.77 \%(p<0.001)$ (Fig. 2$)$.

\section{Subgroup analysis}

Since this meta-analysis exhibited a considerable heterogeneity, subgroup analysis was done using study group, study quality, region/ city where the studies were conducted, year of publication, data collection year, sampling technique, screening method, and the setting was considered to identify the possible sources of heterogeneity among the studies. The subgroup analysis indicated that the heterogeneity level was slightly reduced among pregnant women $\left(I^{2}=52.2 \%\right)$, HIV positive study participants $\left(I^{2}=64.59 \%\right)$, studies conducted in SNNPR $\left(I^{2}=67.13 \%\right)$, studies conducted using probability sampling technique $\left(I^{2}=80.13 \%\right)$, and among studies those did not clearly indicated their sampling techniques $\left(I^{2}=\% 41.91\right)$. Geographically, the highest and the lowest prevalence of HBV were obtained from the Addis Ababa city 10\% (95\% CI: 6, 15\%) and Amhara region 4\% (95\% CI: $3,5 \%)$, respectively. Studies conducted on nonprobability sampling accounted for the highest 7\% (95\% CI: $5,9 \%)$ followed by studies conducted through a survey. Concerning screening techniques, studies conducted using ELISA accounted for the least prevalence estimate of $4 \%$ (95\% CI: $4,5 \%$ ) (Table 2).

\section{Meta-regression and sensitivity analysis}

A meta-regression analysis was done on the categorical variables including year of study, year of publication, study group, region, sample size, sampling technique, quality score, and screening methods. Among these variables, year of data collection was borderline significant. The remaining covariates including region/ city $(p=0.04)$, study group $(p=0.005)$, screening method $(p=0.017)$ and quality of papers $(p=0.001)$ were significantly associated with HBV pooled prevalence (Table 3). Sensitivity analysis was performed by removing a single study from the analysis in order to ensure the stability of the overall effect estimate. The result indicated that removing a single study from the analysis did not significantly influence the pooled estimate (Additional file 2).

\section{Publication bias and small study effects}

The presence of publication bias was evaluated using funnel plots and Egger's test. Each point in funnel plots represents a separate study and asymmetrical distribution indicates the presence of publication bias [5]. First, studies' effect sizes were plotted against their standard errors and the visual evaluation of the funnel plot indicated no publication bias as the graph appear symmetrical (Fig. 3). The subjective evidence from the funnel plot was objectively confirmed using the Egger's weighted regression statistics. According to the symmetry assumption, the $p$-value of 
Table 1 Characteristics of the included studies in the systematic review and meta-analysis for the prevalence of hepatitis B virus in Ethiopia, 2019

\begin{tabular}{|c|c|c|c|c|c|c|c|c|}
\hline First author, year & P. year & Region & Study group & Sampling technique & Sample & $\mathrm{HBsAg}+$ & D. method & Quality \\
\hline Abate M., et al. [80] & 2016 & Somali & Blood donor & Entire sampling & 2752 & 166 & ELISA & Good \\
\hline Abera B., et al. [79] & 2017 & Amhara & HIV positive children & Random sampling & 253 & 5 & ELISA & Good \\
\hline Abera B., et al. [78] & 2014 & Amhara & Apparently healthy & Random sampling & 481 & 15 & RDT & Good \\
\hline Akalu GT., et al. [77] & 2016 & SAC & Healthcare workers & Convenient sampling & 313 & 55 & $\mid A$ & Poor \\
\hline Amsalu A., et al. [76] & 2018 & SNNPR & Pregnant women & Consecutive sampling & 475 & 34 & ELISA & Good \\
\hline Anagaw B., et al. [75] & 2012 & Amhara & Waste handlers & Unknown & 200 & 6 & RDT & Good \\
\hline Asfaw MA., et al. [74] & 2018 & SNNPR & VCT & Random sampling & 331 & 29 & RDT & Good \\
\hline Ataro Z., et al. [73] & 2018 & SAC & Blood donors & Entire sampling & 6376 & 298 & ELISA & Good \\
\hline Ayele AG., et al. [72] & 2013 & SAC & Chronic liver diseases & Convenient sampling & 120 & 43 & RDT & Poor \\
\hline Balew M., et al. [71] & 2014 & Amhara & HIV positive & Random sampling & 395 & 24 & RDT & Poor \\
\hline Belayneh F., [70] & 2015 & SNNPR & HIV positive adult & Consecutive sampling & 348 & 24 & RDT & Good \\
\hline Betela B., et al. [87] & 2018 & Oromia & General population & Random sampling & 1343 & 146 & RDT & Poor \\
\hline Biadgo B., et al. [69] & 2017 & Amhara & Blood donors & Entire sampling & 2294 & 121 & ELISA & Good \\
\hline Bialfew Y., et al. [68] & 2018 & Amhara & Blood donors & Consecutive sampling & 403 & 19 & ELISA & Good \\
\hline Birku T., et al. [67] & 2015 & Amhara & Military personnel & Random sampling & 403 & 17 & RDT & Good \\
\hline Bisetegen FS., et al. [66] & 2016 & SNNPR & Blood donors & Consecutive sampling & 390 & 11 & ELISA & Good \\
\hline Chernet A., et al. [65] & 2017 & SNNPR & Pregnant women & Entire sampling & 289 & 10 & RDT & Good \\
\hline Dabsu R., et al. [64] & 2014 & Oromia & Pregnant women & Convenient sampling & 421 & 10 & RDT & Good \\
\hline Demsiss W., et al. [63] & 2018 & Amhara & Students & Random sampling & 422 & 17 & ELISA & Good \\
\hline Deressa T., et al. [20] & 2017 & Amhara & HIV positive & Random sampling & 308 & 17 & PCR & Good \\
\hline Deressa T., et al. [62] & 2018 & Amhara & Blood donors & Entire sampling & 8460 & 102 & ELISA & Poor \\
\hline Desalegn Z., et al. [84] & 2013 & SAC & Healthcare workers & Convenient sampling & 254 & 6 & $\mid A$ & Good \\
\hline Desalegn Z., et al. [83] & 2016 & Oromia & Pregnant women & Entire sampling & 202 & 11 & ELISA & Good \\
\hline Erena AN., et al. [61] & 2014 & Oromia & General population & Random sampling & 353 & 26 & $\mid \mathrm{A}$ & Good \\
\hline G/micheal A., et al. [60] & 2013 & Oromia & Healthcare workers & Random sampling & 220 & 9 & RDT & Poor \\
\hline G/egziabher D., et al. [59] & 2016 & SAC & General population & Entire sampling & 482 & 102 & RDT & Poor \\
\hline G/mariam AA., et al. [58] & 2019 & Amhara & Healthcare professional & Entire sampling & 332 & 15 & RDT & Good \\
\hline Habte Y., et al. [57] & 2016 & SAC & Blood donors & Entire sampling & 4157 & 155 & ELISA & Good \\
\hline Hebo HJ., et al. [56] & 2019 & Oromia & Healthcare workers & Random sampling & 240 & 6 & ELISA & Good \\
\hline Heyredin I., et al. [55] & 2019 & Mixed & Blood donors & Consecutive sampling & 500 & 33 & ELISA & Good \\
\hline Kabato AA., et al. [86] & 2016 & SNNPR & Blood donors & Entire sampling & 359 & 17 & ELISA & Good \\
\hline Kebede W., et al. [85] & 2017 & Oromia & Prisoners & Random sampling & 156 & 9 & ELISA & Good \\
\hline Mekonnen A., et al. [54] & 2015 & SAC & Waste handlers & Random sampling & 252 & 9 & ELISA & Good \\
\hline Mekonnen D., et al. [53] & 2014 & Amhara & Diabetes mellitus & * & 108 & 4 & RDT & Poor \\
\hline Metaferia Y., et al. [52] & 2016 & SNNPR & Pregnant women & Convenient sampling & 269 & 21 & ELISA & Good \\
\hline Mezgebo TA., et al. [81] & 2018 & Tigray & Pregnant women & $*$ & 328 & 18 & IA & Good \\
\hline Mohammed Y., et al. [51] & 2016 & Somali & Blood donors & Entire sampling & 4224 & 460 & ELISA & Good \\
\hline Molla S., et al. [50] & 2015 & Amhara & Pregnant women & Random sampling & 384 & 17 & RDT & Good \\
\hline Negash M., et al. [49] & 2019 & Amhara & Blood donors & Entire sampling & 310 & 18 & ELISA & Good \\
\hline Negero A., et al. [48] & 2011 & Oromia & VCT & Entire sampling & 384 & 22 & RDT & Good \\
\hline Schonfeld A., et al. [47] & 2018 & Oromia & Pregnant women & Consecutive sampling & 580 & 31 & RDT & Good \\
\hline Seid M., et al. [46] & 2014 & Amhara & Pregnant women & Random sampling & 385 & 19 & ELISA & Good \\
\hline Shiferaw E., et al. [44] & 2019 & Amhara & Blood donors & Entire sampling & 35,435 & 230 & ELISA & Good \\
\hline
\end{tabular}


Table 1 Characteristics of the included studies in the systematic review and meta-analysis for the prevalence of hepatitis B virus in Ethiopia, 2019 (Continued)

\begin{tabular}{|c|c|c|c|c|c|c|c|c|}
\hline First author, year & P. year & Region & Study group & Sampling technique & Sample & $\mathrm{HBsAg}+$ & D. method & Quality \\
\hline Shiferaw Y., et al. [45] & 2011 & SAC & Waste Handlers & Random sampling & 252 & 9 & ELISA & Good \\
\hline Shimelis T., et al. [43] & 2017 & SNNPR & HIV positive & $*$ & 477 & 30 & RDT & Good \\
\hline Shure W., et al. [42] & 2018 & SAC & Barbers & Convenient sampling & 400 & 15 & ELISA & Good \\
\hline Taye S., et al. [41] & 2014 & Oromia & Chronic hepatitis & Entire sampling & 358 & 80 & RDT & Poor \\
\hline Tegegne D., et al. [40] & 2014 & SAC & Pregnant women & * & 265 & 8 & ELISA & Good \\
\hline Teklemariam Z., et al. [40] & 2018 & Harari & Blood donors & Entire sampling & 4107 & 167 & ELISA & Good \\
\hline Tesfa H., et al. [38] & 2013 & Amhara & Clinically suspected & Entire sampling & 2684 & 382 & RDT & Good \\
\hline Tessema B., et al. [37] & 2010 & Amhara & Blood donors & Entire sampling & 6361 & 299 & ELISA & Good \\
\hline Tigabu A., et al. [36] & 2019 & Amhara & Blood donors & Entire sampling & 5983 & 244 & ELISA & Good \\
\hline Tiruye G., et al. [35] & 2018 & Harari & Pregnant women & Random sampling & 320 & 20 & ELISA & Good \\
\hline Umare A., et al. [34] & 2016 & Oromia & Pregnant women & Consecutive sampling & 318 & 22 & ELISA & Poor \\
\hline Weldemhret L., et al. [33] & 2016 & Tigray & HIV positive & $*$ & 508 & 30 & ELISA & Good \\
\hline Wondimeneh Y., et al. [82] & 2013 & Amhara & HIV positive & Consecutive sampling & 400 & 20 & RDT & Good \\
\hline Yami A., et al. [32] & 2011 & Oromia & Blood donors & Entire sampling & 6063 & 126 & ELISA & Good \\
\hline Yizengaw E., et al. [31] & 2018 & Amhara & Healthcare workers & Random sampling & 388 & 10 & ELISA & Good \\
\hline Yohanes T., et al. [30] & 2016 & SNNPR & Pregnant women & Random sampling & 232 & 10 & ELISA & Good \\
\hline Zenebe Y., et al. [29] & 2014 & Amhara & Pregnant women & Random sampling & 318 & 12 & ELISA & Good \\
\hline
\end{tabular}

Key: SAC Self-Administrative City, SNNPR Southern Nations, Nationalities and Peoples' Region, ELISA Enzyme-Linked Immunosorbent Assay, RDT Rapid Diagnostic Test, IA Immunoassay, VCT volunteer for counseling and testing

*: not stated

0.747 declares the absence of small study effects among the included studies.

\section{Discussion}

Viral hepatitis is a serious disease which is caused by a number of hepatotropic viruses. Among these, HBV is by far the most clinically important pathogen that can cause both acute and chronic disease. Though there is recent scientific and clinical advancement of the antiviral therapy, this pathogen is still a major public health concern globally, particularly among the developing countries [88, 89]. Hepatitis B virus prevalence is highly variable among different parts of the globe. Even it is inconsistent between studies within a country including Ethiopia. Therefore, in this review, we estimated the overall pooled prevalence of HBV among the Ethiopian population.

In the current study, all the included studies were cross-sectional and are therefore the indicators of the point prevalence of the disease. Considering this, HBV prevalence was ranged from 1 to $36 \%[62,72]$ depending on the study population characteristics, study period, study design, and methods of laboratory screening. In most studies, the prevalence was lower than $8 \%$, the threshold value of high transmission areas definition, $[90,91]$. In this review, though the overall pooled prevalence estimate (6\%) showed a slight decrement compared to the previous estimation (7.4\%) [19], it is still a burden that represents an additional challenge for the national health system which is already fighting with the different infectious and noninfectious disease. In comparison to other studies conducted elsewhere, the result was more or less comparable to a finding from Thailand $5.1 \%$ [92]. However, it was significantly exceeded the global estimation (3.61\%) and a finding from Iran (3\%) $[93,94]$. On the other hand, relatively far high estimates were obtained from Sudan 12.07\%, Cameroon 10.6\%, Burkina Faso 11.21\%, Ghana 12.3\%, Nigeria 13.6\%, East Asia 8.6\%, WHO Africa region 8.83\%, and Somalia 19\% [8, 93, 95-100]. The possible explanation for this great difference could be due to the fact that HBV might be hyperendemic in the mentioned countries. In addition, socio-cultural factors, level of awareness and infection prevention practice by the community, and the levels of stakeholder involvement in infection prevention could be considered as a possible factors for the high or low level of prevalence estimates.

Though the pooled prevalence (4\%) of $\mathrm{HBV}$ among blood donors was significantly decreased compared to the previous estimate $8.4 \%$ [19], our study raised concerns on strict adherence of safe blood supply in Ethiopia as 1 in 25 (4\%) blood donors might be infected with the virus. As a control strategy, if the system includes rigorous blood screening techniques before transfusion and sensitization of blood donors with recent potential risky behavior to avoid infective blood donation. The decreased pooled 


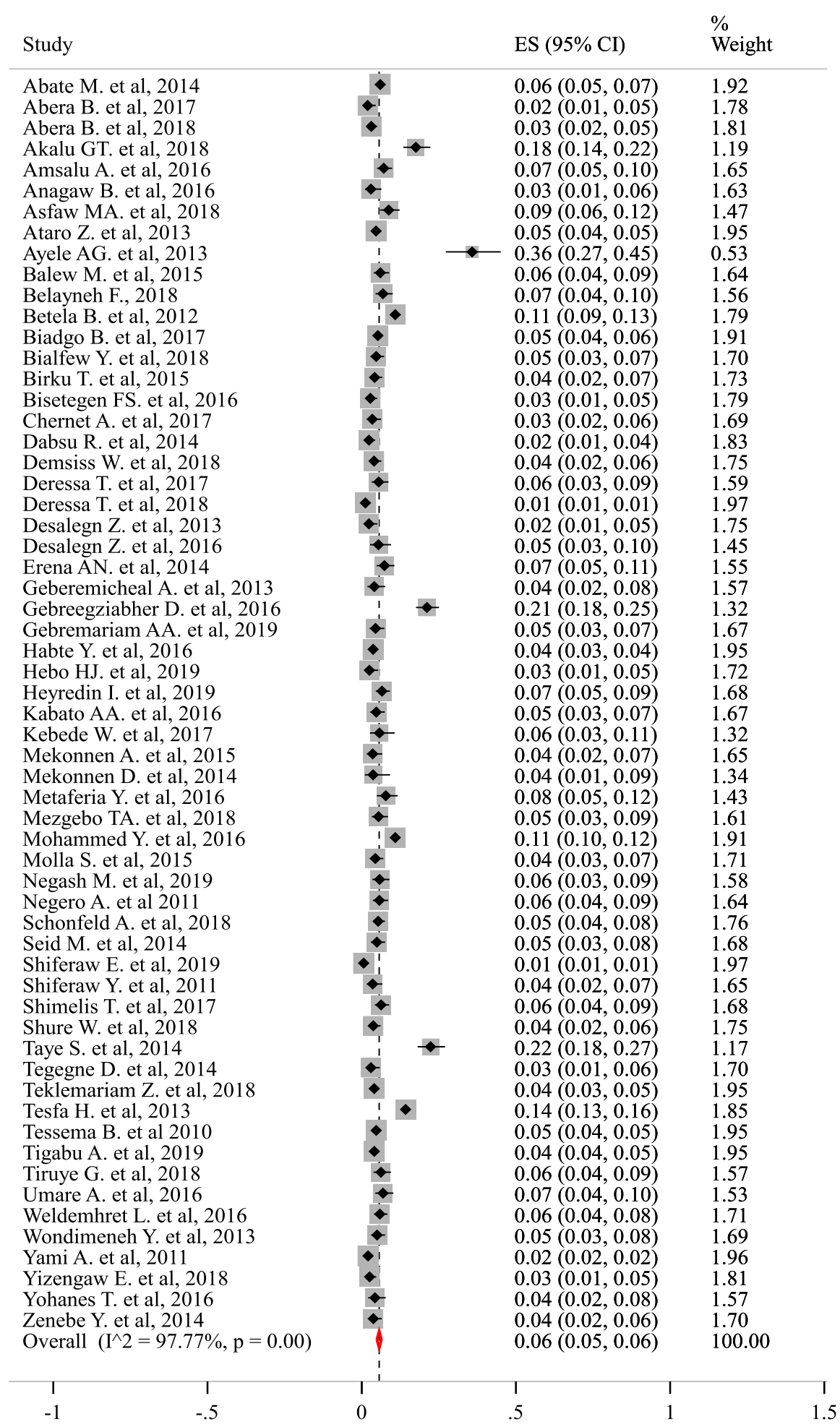

Proportion

Fig. 2 The pooled prevalence estimate of HBV in Ethiopia from 2010 to 2019 
Table 2 Subgroup analysis of the HBV pooled prevalence estimation in Ethiopia, 2019

\begin{tabular}{|c|c|c|c|c|c|}
\hline Moderator variables & Variable category & Included studies & Prevalence \% (95\% Cl) & $1^{2} \%$ & $\% P$-value \\
\hline \multirow[t]{5}{*}{ Study group } & Blood donor & 16 & $4(0.03,0.06)$ & 98.99 & 0.00 \\
\hline & Pregnant women & 14 & $5(0.04,0.06$ & 52.20 & 0.01 \\
\hline & Healthcare worker & 6 & $5(0.05,0.08)$ & 89.47 & 0.00 \\
\hline & HIV positive & 7 & $5(0.04,0.07)$ & 64.59 & 0.01 \\
\hline & Others & 17 & $9(0.06,0.11)$ & 95.69 & 0.00 \\
\hline \multirow[t]{2}{*}{ Study quality } & Good quality & 50 & $5(0.04,0.06)$ & 97.74 & 0.00 \\
\hline & Poor quality & 10 & $12(0.07,017)$ & 98.12 & 0.00 \\
\hline \multirow[t]{5}{*}{ Region/ city } & Amhara & 22 & $4(0.03,0.05)$ & 97.95 & 0.00 \\
\hline & Oromia & 12 & $6(0.04,0.09)$ & 95.08 & 0.00 \\
\hline & SNNPR & 9 & $6(0.04,0.07)$ & 67.13 & 0.00 \\
\hline & Addis Ababa city & 8 & $10(0.06,0.15)$ & 96 & 0.00 \\
\hline & Others & 9 & $6(0.04,0.07)$ & 95.77 & 0.00 \\
\hline \multirow[t]{3}{*}{ Year of publication } & 2010-2012 & 5 & $4(0.02,0.05)$ & 94.44 & 0.00 \\
\hline & 2013-2015 & 18 & $7(0.05,0.09)$ & 94.85 & 0.00 \\
\hline & 2016-2019 & 37 & $6(0.05,0.07)$ & 98.02 & 0.00 \\
\hline \multirow[t]{3}{*}{ Year of study } & 2010-2012 & 12 & $5(0.03,0.06)$ & 92.28 & 0.00 \\
\hline & 2013-2015 & 26 & $5(0.05,0.06)$ & 85.59 & 0.00 \\
\hline & 2016-2019 & 12 & $6(0.04,0.07)$ & 89.54 & 0.00 \\
\hline \multirow[t]{4}{*}{ Sampling techniques } & Probability & 20 & $5(0.04,0.06)$ & 80.13 & 0.00 \\
\hline & Non-probability & 14 & $7(0.05,0.09)$ & 89.56 & 0.00 \\
\hline & Survey & 20 & $6(0.05,0.07)$ & 99.07 & 0.00 \\
\hline & Not stated & 6 & $5(0.03,0.06)$ & 41.91 & 0.105 \\
\hline \multirow[t]{3}{*}{ Diagnosis method } & ELISA & 34 & $4(0.04,0.05)$ & 97.98 & 0.00 \\
\hline & RDT & 21 & $8(0.06,0.10)$ & 95.07 & 0.00 \\
\hline & $\mathrm{IA}$ & 4 & $8(0.03,0.13)$ & 93.20 & 0.00 \\
\hline \multirow[t]{2}{*}{ Setting } & Urban & 39 & $6(0.05,0.07)$ & 98.41 & 0.00 \\
\hline & Mixed & 21 & $5(0.05,0.06)$ & 90.93 & 0.00 \\
\hline
\end{tabular}

Key: ELISA Enzyme-Linked Immunosorbent Assay, IA Immunoassay, RDT Rapid Diagnostic Test; SNNPR Southern Nations, Nationalities and Peoples Region

prevalence could be due to increased awareness of the community regarding infection prevention and increased attention and involvement of stakeholders. However, a lower prevalence estimate (2.03\%) was obtained from the Eastern Mediterranean countries [101]. The current prevalence among blood donors was much lower than findings from Nigeria 14\%, Ghana 11.75\%, Burkina Faso

Table 3 Meta-regression analysis of factors for the heterogeneity of HBV prevalence in Ethiopia, 2019

\begin{tabular}{lllll}
\hline Moderator & Coefficient & Std. Error & $P$-value & Adjusted R $^{2}(\%)$ \\
\hline Data collection year & .1547288 & .0859943 & 0.077 & 4.07 \\
Region/ city & .1328385 & .0631128 & 0.040 & 5.98 \\
Study group & .1623181 & .0559312 & 0.005 & 13.81 \\
Screening method & .3274201 & .132906 & 0.017 & 9.54 \\
Quality of papers & .8060166 & .2361892 & 0.001 & 16.66 \\
\hline
\end{tabular}

11.73\%, and Cameroon 10.5\% [96-99]. The possible explanation could be due to high endemicity of the virus in the said countries than Ethiopia.

Concerning HBV among pregnant women, a high (5\%) prevalence was noted that require prompt screening of pregnant women during their antenatal care visit and provide proper treatment to decrease the rate of mother to child transmission of the virus. Though the result was far higher than recent findings from India 1.01\% [102] and Iran (1.18 and 1.25\%) conducted at different time periods [103, 104], it was significantly lower compared to the findings from Nigeria $14.1 \%$, Cameroon $11.11 \%$, Burkina Faso 9.8\%, and Ghana 13.1\% [96-99]. Most probability this variability could be due to the endemicity of the virus among the mentioned countries than Ethiopia or it could be due to the increased attention of the Ethiopian government in providing care and follow- 


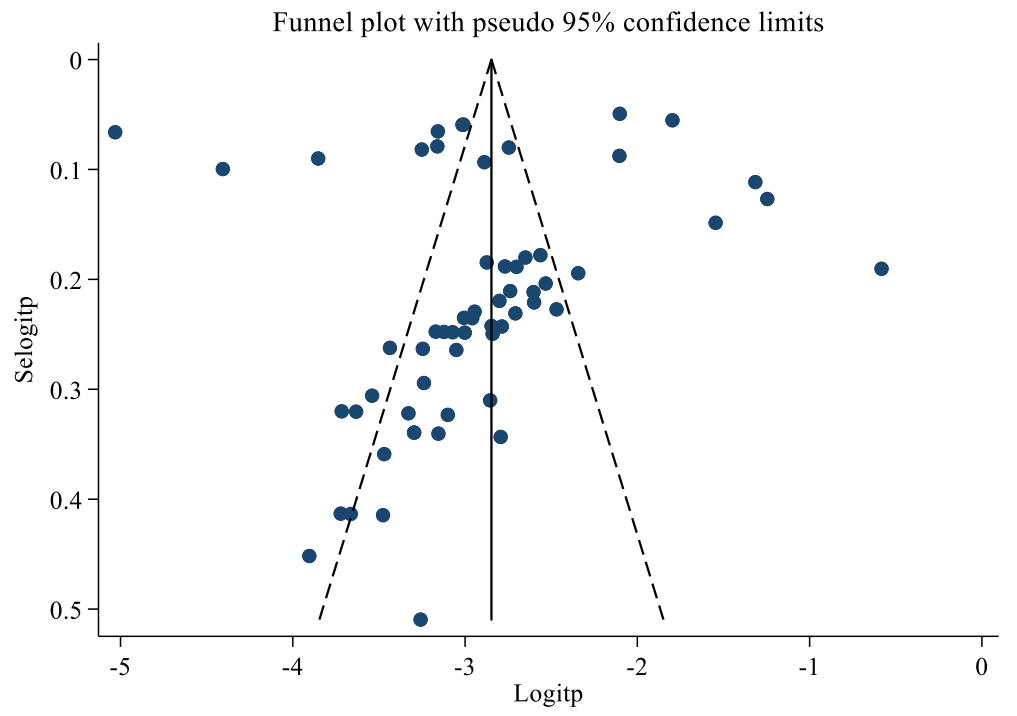

Fig. 3 Funnel plot of the prevalence of HBV in Ethiopia from 2010 to 2019

up for the pregnant women which could significantly reduce the transmission and prevalence of $\mathrm{HBV}$ among the pregnant women.

Similarly, the pooled prevalence estimate among health workers was accounted for $5 \%$. This high prevalence could be due to the fact that health professionals are frequently exposed to risky biological fluids that might be infected with the virus. The prevalence was however lower than a finding from Cameron 9.5\% [96]. The possible explanation for this difference could be due to the difference in viral endemicity between the nations, awareness, potential exposure in risky medical procedures, over workload, and working hours per day could be possible predisposing factors that could be considered while analyzing the factors responsible for the difference in prevalence estimates. The current prevalence (7\%) among HIV was exactly similar to the previous estimate of 7\% [19]. However, the result was lower than findings from Nigeria 13.6\%, Burkina Faso 12.61\%, and Cameron $12.9 \%[96,99,105]$. For this reason, viral endemicity, community awareness on infection prevention, and the role of stakeholders with respect to infection prevention and control could the potential factors. Though the current prevalence of HBV among HIV patients was considerably low compared to the findings from the aforementioned counties, an urgent measure should be implemented to manage this vulnerable group as they appear more at risk than the general population.

Though there was no influence on the overall effect estimate while removing a single study at a time from the analysis, we tried to assess the possible sources of variability through subgroup analysis and meta-regression. In the subgroup analysis, the level of heterogeneity was significantly reduced among studies conducted on pregnant women and HIV positive study participants. On the other hand, the $I^{2}$ value did not significantly reduce among regional subgroup analysis. The highest (4\%) and least (10\%) prevalence estimates were obtained from the Amhara region and Addis Ababa city, respectively. The low prevalence estimate in the Amhara region could be due to better awareness of the community to HBV disease. Whereas, the high prevalence from the Addis Ababa city could be due to the fact that a study with high prevalence among chronic liver disease was included in the study that might affect the overall pooled prevalence estimate in that area. The heterogeneity level did not reduce among quality score subgroup analysis, but significantly high prevalence estimate was noted on those studies with poor quality that could be due to sampling bias among poor quality studies. Concerning screening methods, a low prevalence estimate was obtained among studies conducted with ELISA than studies conducted with RDT or IA screening techniques. This could be due to the high specificity of ELISA than RDT or IA screening techniques. Further, the possible sources of heterogeneity were analyzed through meta-regression and finally, province, study group, screening method, and quality of papers were identified as having a statistically significant association with HBV prevalence.

\section{Limitations}

The current review has incurred several limitations which includes lack of study from the BenishangulGumuz and Afar regions. Even the number of studies obtained from the Tigray, Harari, and Somali regions were very limited. In addition, the inconsistency of screening methods might also be significantly contributed to the heterogeneity of the pooled estimate. Due to 
these reasons, the results of this systematic review and meta-analysis might compromise the overall pooled prevalence estimate of $\mathrm{HBV}$ in Ethiopia. Nevertheless, the current study provides an insight into the burden of HBV in Ethiopia and could promote the development of appropriate measures.

\section{Conclusions}

The pooled prevalence of HBV was high in Ethiopia and it is a major public health threat. Since large numbers of recent studies were included in the review, it can clearly indicate the current prevalence and epidemiology of HBV in the country that could be valuable for policymakers. Therefore, strengthening the scope of the existing vaccination program and the establishment of new sensitive screening methods is highly recommended. In addition, it will be better if the existing infection prevention program is revised and target specific task force should be organized at different levels of health facilities in order to increase the awareness of the community. Control efforts should be scaled up countrywide and novel approaches including screen-and-treat could be implemented to reduce the burden of the disease in Ethiopia. Further political will and strong community awareness will be key to effectively tackling the burden of HBV problem in Ethiopia. Additional study should be conducted particularly in those regions where studies did not conduct so far to fully understand the dynamics of HBV burden in Ethiopia.

\section{Supplementary information}

Supplementary information accompanies this paper at https://doi.org/10. 1186/s12879-019-4486-1.

Additional file 1. PubMed search string.

Additional file 2. Sensitivity analysis of HBV prevalence in Ethiopia.

\section{Abbreviations \\ DARE: Database of Abstracts of Reviews of Effects; ELISA: Enzyme-Linked Immunosorbent Assay; HBcAb: Hepatitis B Core Antibody; HBeAb: Hepatitis B Pre-core Antibody; HBeAg: Hepatitis B Pre-core Antigen; HBsAb: Hepatitis B Surface Antibody; HBsAg: Hepatitis B Surface Antigen; HBV: Hepatitis B Virus; HIV: Human Immunodeficiency Virus; IA: Immunoassay; JBI: Joanna Briggs Institute; PRISMA: Preferred Reporting Items for Systematic Reviews and Meta-Analyses; PRISMA-P: Preferred Reporting Items for Systematic Reviews and Meta-Analysis Protocols; RDT: Rapid Diagnostic Tests; SNNPR: Southern Nations, Nationalities and Peoples Region; VCT: Volunteer for Counseling and Testing; WHO: World Health Organization}

\section{Acknowledgments}

Authors of this article would like to thank all the authors of the primary studies and biomedical staffs for review of the final manuscript.

\section{Authors' contributions}

TDY and MGT conceptualized the systematic review and meta-analysis, searched articles and screened based on the eligibility criteria. Both authors extracted data files from the full-text articles. TDY contributed to the statistical analysis and both authors involved in the write-up of the draft manuscript. TDY finalized the manuscript and communicated with the journal. Both authors read and approved the final manuscript before submission.

\section{Funding}

This research did not receive any grant.

Availability of data and materials

All the data generated or analyzed are included in this manuscript and attached as an additional files.

Ethics approval and consent to participate

Not applicable.

\section{Consent for publication}

Not applicable.

\section{Competing interests}

The authors declare that they have no competing interests.

Received: 16 July 2019 Accepted: 20 September 2019

Published online: 29 October 2019

\section{References}

1. Stanaway JD, Flaxman AD, Naghavi M, Fitzmaurice C, Vos T, Abubakar I, et al. The global burden of viral hepatitis from 1990 to 2013: findings from the global burden of disease study 2013. Lancet. 2016:388:1081-8.

2. Chonwattana W, Raengsakulrach B, Holtz TH, Wasinrapee P, Tongtoyai J, Chaikummao $S$, et al. Hepatitis B vaccination uptake and correlates of serologic response among HIV-infected and uninfected men who have sex with men (MSM) in Bangkok, Thailand. Vaccine. 2016;34:2044-50.

3. World Health Organization. Hepatitis B vaccines. Weekly Epidemiological Record (WER). 2009;40:405-420. https://www.who.int/wer/2009/wer8440/ en/.

4. Mba JM, Bisseye C, Ndong JM, Mombo LE, Bengone C, Migolet GM, et al. Prevalent hepatitis B surface antigen among first-time blood donors in Gabon. PLoS One. 2018;13:e0194285.

5. Ziraba AK, Bwogi J, Namale A, Wainaina CW, Mayanja-Kizza H. Seroprevalence and risk factors for hepatitis $B$ virus infection among health care workers in a tertiary hospital in Uganda. BMC Infect Dis. 2010;10:191.

6. Mahoney FJ. Update on diagnosis, management, and prevention of hepatitis B virus infection. Clin Microbiol Rev. 1999;12:351-66.

7. Tao I, Compaoré TR, Diarra B, Djigma F, Zohoncon TM, Assih M, et al. Seroepidemiology of hepatitis $B$ and $C$ viruses in the general population of Burkina Faso. Hepatitis Res Treatment. 2014;2014:781843.

8. Ott JJ, Stevens GA, Groeger J, Wiersma ST. Global epidemiology of hepatitis $B$ virus infection: new estimates of age-specific HBsAg seroprevalence and endemicity. Vaccine. 2012;30:2212-9.

9. Lavanchy D. Hepatitis B virus epidemiology, disease burden, treatment, and current and emerging prevention and control measures. J Viral Hepat. 2004:11:97-107.

10. Ryerson AB, Eheman CR, Altekruse SF, Ward JW, Jemal A, Sherman RL, et al. Annual report to the nation on the status of cancer, 1975-2012, featuring the increasing incidence of liver cancer. Cancer. 2016;122:1312-37.

11. Abubakar II, Tillmann T, Banerjee A. Global, regional, and national age-sex specific all-cause and cause-specific mortality for 240 causes of death, 19902013: a systematic analysis for the global burden of disease study 2013. Lancet. 2015:385:117-71.

12. Pruss-Ustün A, Rapiti E, Hutin Y. Estimation of the global burden of disease attributable to contaminated sharps injuries among health-care workers. Am $J$ Ind Med. 2005;48:482-90.

13. Akibu M, Nurgi S, Tadese M, Dibekulu WD. Attitude and vaccination status of healthcare workers against hepatitis B infection in a teaching hospital, Ethiopia. Scientifica. 2018;2018:1-8. https://www.hindawi.com/journals/ scientifica/2018/6705305/.

14. Blumberg BS. Hepatitis B: the hunt for a killer virus. London: Princeton University Press; 2002. p. 264.

15. Terrault NA, Bzowej NH, Chang KM, Hwang JP, Jonas MM, Murad MH. American Association for the Study of Liver D. AASLD guidelines for treatment of chronic hepatitis B. Hepatology. 2016;63:261-83.

16. Lozano R, Naghavi M, Foreman K, Lim S, Shibuya K, Aboyans V, et al. Global and regional mortality from 235 causes of death for 20 age groups in 1990 and 2010: a systematic analysis for the global burden of disease study 2010. Lancet. 2012:380:2095-128. 
17. Asfaw N, Zufan S, Girmay M. Prevalence of hepatitis B surface antigen (HBs ag) among visitors of Shashemene general hospital voluntary counseling and testing center. BMC Research Notes. 2011;4:35.

18. Eckman MH, Kaiser TE, Sherman KE. The cost-effectiveness of screening for chronic hepatitis B infection in the United States. Clin Infect Dis. 2011;52: 1294-306.

19. Belyhun Y, Maier M, Mulu A, Diro E, Liebert UG. Hepatitis viruses in Ethiopia: a systematic review and meta-analysis. BMC Infect Dis. 2016;16:761.

20. Deressa T, Damtie D, Fonseca K, Gao S, Abate E, Alemu S, et al. The burden of hepatitis $B$ virus (HBV) infection, genotypes and drug resistance mutations in human immunodeficiency virus-positive patients in Northwest Ethiopia. PLoS One. 2017;12:e0190149.

21. Ambachew H, Zheng M, Pappoe F, Shen J, Xu Y. Genotyping and serovirological characterization of hepatitis B virus (HBV) in blood donors, Southern Ethiopia. PLoS One. 2018;13:e0193177.

22. Shamseer L, Moher D, Clarke M, Ghersi D, Liberati A, Petticrew M, et al. Preferred reporting items for systematic review and meta-analysis protocols (PRISMA-P) 2015: elaboration and explanation. Br Med J. 2015;349:7647.

23. Moher D, Liberati A, Tetzlaff J, Altman DG. Preferred reporting items for systematic reviews and meta-analyses: the PRISMA statement. PLoS Med. 2009;6:e1000097.

24. The Joanna Briggs Institute. Critical Appraisal tools for use in JBI Systematic Reviews Checklist for Prevalence Studies: The University of Adelaide: Available from: https://joannabriggs.org/research/critical-appraisal-tools.html.

25. Borenstein M, Hedges LV, Higgins PT, Rothstein HR. Introduction to metaanalysis. United Kingdom: Wiley; 2011. 2009.

26. George J, Aban IB. An application of meta-analysis based on DerSimonian and Laird method. J Nucl Cardiol. 2016;23:690-2.

27. Ades AE, Lu G, Higgins JP. The interpretation of random-effects metaanalysis in decision models. Med Decis Mak. 2005;25:646-54.

28. Wang J, Wu X, Lai W, Long E, Zhang X, Li W, et al. Prevalence of depression and depressive symptoms among outpatients: a systematic review and meta-analysis. BMJ Open. 2017;7:e017173.

29. Zenebe $Y$, Mulu W, Yimer M, Abera B. Sero-prevalence and risk factors of hepatitis $B$ virus and human immunodeficiency virus infection among pregnant women in Bahir Dar city, Northwest Ethiopia: a cross sectional study. BMC Infectious Dis. 2014;14:118.

30. Yohanes T, Zerdo Z, Chufamo N. Seroprevalence and predictors of hepatitis B virus infection among pregnant women attending routine antenatal care in Arba Minch hospital, South Ethiopia. Hepatitis Res Treat. 2016;2016:9290163.

31. Yizengaw E, Getahun T, Geta M, Mulu W, Ashagrie M, Hailu D, et al. Seroprevalence of hepatitis $B$ virus infection and associated factors among health care workers and medical waste handlers in primary hospitals of north-West Ethiopia. BMC Research Notes. 2018;11:437.

32. Yami A, Alemseged F, Hassen A. Hepatitis B and C viruses infections and their association with human immunodeficiency virus: a cross-sectional study among blood donors in Ethiopia. Ethiop J Health Sci. 2011;21:67-75.

33. Weldemhret L, Asmelash T, Belodu R, Gebreegziabiher D. Sero-prevalence of HBV and associated risk factors among HIV positive individuals attending ART clinic at Mekelle hospital, Tigray, Northern Ethiopia. AIDS Res Therapy. 2016;13:6.

34. Umare A, Seyoum B, Gobena T, Mariyam TH. Hepatitis B virus infections and associated factors among pregnant women attending antenatal Care Clinic at Deder Hospital, Eastern Ethiopia. PLoS One. 2016;11:e0166936.

35. Tiruye G, Shiferaw K, Tadesse F. Seroprevalence of hepatitis B virus infection and associated factors among pregnant women attended antenatal care services in Harar city, Eastern Ethiopia. J Women's Health Care. 2018;7:3.

36. Tigabu A, Engda T, Mekonnen F. Seroprevalence of transfusion transmissible viral infections (HIV, HBV and HCV) among voluntary blood donors at University of Gondar Comprehensive Specialized Hospital, Gondar; Northwest Ethiopia. BMC Infect Dis. 2019;19:393.

37. Tessema B, Yismaw G, Kassu A, Amsalu A, Mulu A, Emmrich F, et al. Seroprevalence of HIV, HBV, HCV and syphilis infections among blood donors at Gondar University Teaching Hospital, Northwest Ethiopia: declining trends over a period of five years. BMC Infect Dis. 2010;10:111.

38. Tesfa H, Biadgo B, Getachew F, Tegegne K, Yismaw G, Muluye D. Seroprevalence of hepatitis $B$ and $C$ virus infection among patients attending serology laboratory of Gondar University Hospital. BMC Res Notes. 2013;6:164.

39. Teklemariam Z, Mitiku H, Weldegebreal F. Seroprevalence and trends of transfusion transmitted infections at Harar blood bank in Harari regional state, Eastern Ethiopia: eight years retrospective study. BMC Hematol. 2018;18:24.

40. Tegegne D, Desta K, Tegbaru B, Tilahun T. Seroprevalence and transmission of hepatitis $B$ virus among delivering women and their new born in selected health facilities, Addis Ababa, Ethiopia: a cross sectional study. BMC Res Notes. 2014;7:239.

41. Taye S, Abdulkerim A, Hussen M. Prevalence of hepatitis B and C virus infections among patients with chronic hepatitis at Bereka medical center, Southeast Ethiopia: a retrospective study. BMC Res Notes. 2014;7:272.

42. Shure W, Desta K, Diriba R, G/Egzabixier A, Benti G: Magnitude of hepatitis B virus among barbers in Addis Ababa, Ethiopia Austin Hepatol 2018, 3:1008.

43. Shimelis T, Tassachew Y, Tadewos A, Hordofa MW, Amsalu A, Tadesse BT, et al. Coinfections with hepatitis B and C virus and syphilis among HIVinfected clients in Southern Ethiopia: a cross-sectional study. HIV/AIDS (Auckland, NZ). 2017;9:203-10.

44. Shiferaw E, Tadilo W, Melkie I, Shiferaw M. Sero-prevalence and trends of transfusiontransmissible infections among blood donors at Bahir Dar district blood bank, Northwest Ethiopia: a four year retrospective study. PLoS One. 2019;14:e0214755.

45. Shiferaw $Y$, Abebe $T$, Mihret $A$. Hepatitis $B$ virus infection among medical aste handlers in Addis Ababa, Ethiopia. BMC Res Notes. 2011;4:479.

46. Seid M, Gelaw B, Assefa A. Sero-prevalence of HBV and HCV infections among pregnant women attending antenatal Care Clinic at Dessie Referral Hospital, Ethiopia. Adv Life Sci Health. 2014;1:109-20.

47. Schonfeld A, Feldt T, Tufa TB, Orth HM, Fuchs A, Mesfun MG, et al. Prevalence and impact of sexually transmitted infections in pregnant women in Central Ethiopia. Int J STD AIDS. 2018;29:251-8.

48. Negero A, Sisay Z, Medhin G. Prevalence of hepatitis B surface antigen ( $\mathrm{HBsAg}$ ) among visitors of Shashemene general hospital voluntary counseling and testing center. BMC Res Notes. 2011:4:35.

49. Negash M, Ayalew M, Geremew D, Workineh M. Seroprevalence and associated risk factors for HIV, hepatitis B and C among blood donors in South Gondar District blood Bank, Northwest Ethiopia. BMC Infect Dis. 2019;19:430.

50. Molla S, Munshea A, Nibret E. Seroprevalence of hepatitis B surface antigen and anti HCV antibody and its associated risk factors among pregnant women attending maternity ward of Felege Hiwot referral hospital, Northwest Ethiopia: a cross-sectional study. Virol J. 2015;12:204

51. Mohammed $Y$, Bekele A. Seroprevalence of transfusion transmitted infection among blood donors at Jijiga blood bank, eastern Ethiopia: retrospective 4 years study. BMC Research Notes. 2016;9:129.

52. Metaferia Y, Dessie W, Ali I, Amsalu A. Seroprevalence and associated risk factors of hepatitis B virus among pregnant women in southern Ethiopia: a hospital-based cross-sectional study. Epidemiol Health. 2016:38:e2016027.

53. Mekonnen D, Gebreselassie S, Fantaw S, Hunegnaw A, Mihret A. Prevalence of hepatitis B virus in patients with diabetes mellitus: a comparative cross sectional study at Woldiya general hospital, Ethiopia. Pan Afr Med J. 2014;17:40

54. Mekonnen A, Desta K, Damtew E. Prevalence of HBV, HCV and associated risk factors among cleaners at selected public health centers in Addis Ababa, Ethiopia. Int J Basic Appl Virol. 2015;4:35-40.

55. Heyredin I, Mengistie B, Weldegebreal F. Sero-prevalence of transfusion transmittable infections and associated factors among blood donors in eastern Ethiopia: an institutional-based cross-sectional study. SAGE Open Medicine. 2019:7:1-8.

56. Hebo HJ, Gemeda DH, Abdusemed KA. Hepatitis B and C Viral Infection: Prevalence, Knowledge, Attitude, Practice, and Occupational Exposure among Healthcare Workers of Jimma University Medical Center, Southwest Ethiopia. Sci World J. 2019;2019:11.

57. Habte Y, Seyoum B, Alemayehu T. Hepatitis B virus infection and associated factors among blood donors at Dire Dawa, eastern Ethiopia. J Antivirals Antiretrovirals. 2016:8:103-6.

58. Gebremariam AA, Tsegaye AT, Shiferaw YF, Reta MM, Getaneh A. Seroprevalence of Hepatitis B Virus and Associated Factors among Health Professionals in University of Gondar Hospital, Northwest Ethiopia. Adv Prev Med. 2019;2019:5.

59. Gebreegziabher D, Asfeha GG, Gebreyesus HA. Seroprevalence of hepatitis B virus surface antigen ( $\mathrm{HBsAg}$ ) among clients visiting 'Tefera Hailu' memorial hospital, Sekota, Northern Ethiopia. BMC Infect Dis. 2016;16:383.

60. Geberemicheal A, Gelaw A, Moges F, Dagnew M. Seroprevalence of hepatitis $B$ virus infections among health care workers at the Bulle Hora 
Woreda governmental health institutions, southern Oromia, Ethiopia. Environ Occup Sci. 2013;2:9-14.

61. Erena AN, Tefera TB. Prevalence of hepatitis B surface antigen (HBsAg) and its risk factors among individuals visiting Goba general hospital, south East Ethiopia, 2012. BMC Research Notes. 2014;7:833.

62. Deressa T, Birhan W, Enawgaw B, Abebe M, Baynes HW, Desta M, et al. Proportion and predictors of transfusion transmissible infections among blood donors in north Shewa zone, Central North Ethiopia. PLoS One. 2018; 13:e0194083.

63. Demsiss W, Seid A, Fiseha T. Hepatitis B and C: Seroprevalence, knowledge, practice and associated factors among medicine and health science students in Northeast Ethiopia. PLoS One. 2018;13:e0196539.

64. Dabsu R, Ejeta E. Seroepidemiology of hepatitis B and C virus infections among pregnant women attending antenatal Clinic in Selected Health Facilities in east Wollega zone, West Oromia, Ethiopia. BioMed Res Int. 2018;2018:1-9.

65. Chernet A, Yesuf A, Alagaw A. Seroprevalence of hepatitis B virus surface antigen and factors associated among pregnant women in Dawuro zone, SNNPR, Southwest Ethiopia: a cross sectional study. BMC Res Notes. 2017;10:418.

66. Bisetegen FS, Bekele FB, Ageru TA, Wada FW. Transfusion-Transmissible Infections among Voluntary Blood Donors at Wolaita Sodo University Teaching Referral Hospital, South Ethiopia. Can J Infect Dis Med Microbiol. 2016;2016:8254343.

67. Birku T, Gelaw B, Moges F, Assefa A. Prevalence of hepatitis B and C viruses infection among military personnel at Bahir Dar armed forces general hospital, Ethiopia. BMC Res Notes. 2015;8:737.

68. Bialfew Y, Hailu G, Samu T. Prevalence and associated factors of hepatitis B virus infection among blood donors in Debre Markos blood Bank Centre, Northwest Ethiopia, 2018. Epidemiology. 2018;8:2-8.

69. Biadgo B, Shiferaw E, Woldu B, Alene KA, Melku M. Transfusion-transmissible viral infections among blood donors at the North Gondar district blood bank, Northwest Ethiopia: a three year retrospective study. PLoS One. 2017; 12:e0180416.

70. Belayneh F. Prevalence of hepatitis B virus infection and associated factors among HIV positive adults attending ART Clinic at Hawassa referral hospital, SNNPR, Ethiopia. Open Access Library J. 2015;2:e1490.

71. Balew M, Moges F, Yismaw G, Unakal C. Assessment of hepatitis B virus and hepatitis $C$ virus infections and associated risk factors in HIV infected patients at Debretabor hospital, South Gondar, Northwest Ethiopia. Asian Pacific J Trop Dis. 2014;4:1-7.

72. Ayele AG, Gebre-Selassie S. Prevalence and risk factors of hepatitis B and hepatitis $C$ virus infections among patients with chronic liver diseases in public hospitals in Addis Ababa, Ethiopia. ISRN Tropical Med. 2013;2013:7.

73. Ataro Z, Urgessa F, Wasihun T. Prevalence and trends of major transfusion transmissible infections among blood donors in Dire Dawa blood bank, eastern Ethiopia: retrospective study from July 2010 to June 2013. Ethiop J Sci. 2018;28:701.

74. Asfaw MA, Abebo ZH, Kassahun AB. Prevalence of hepatitis B virus, its risk factors and coinfection with human immune deficiency virus among clients of voluntary counseling and testing center in hosanna, southern Ethiopia. J Public Health Epidemiol. 2018;10:443-9.

75. Anagaw B, Shiferaw Y, Anagaw B, Belyhun Y, Erku W, Biadgelegn F, et al. Seroprevalence of hepatitis $B$ and $C$ viruses among medical waste handlers at Gondar town health institutions, Northwest Ethiopia. BMC Res Notes. 2012:5:55.

76. Amsalu A, Ferede G, Eshetie S, Tadewos A, Assegu D. Prevalence, infectivity, and associated risk factors of hepatitis B virus among pregnant women in Yirgalem hospital, Ethiopia: Implication of Screening to Control Mother-toChild Transmission. J Pregnancy. 2018;2018:1-8.

77. Akalu GT, Woldemariam AT, Shewaye AB, Geleta DA, Demise AH, Debele MT, et al. Burden of hepatitis-B infections and risk factors among healthcare Workers in Resource Limited Setting, Addis Ababa, Ethiopia. EC Microbiol. 2016;4:722-31.

78. Abera B, Zenebe Y, Mulu W, Kibret M, Kahsu G. Seroprevalence of hepatitis $B$ and $C$ viruses and risk factors in HIV infected children at the Felgehiwot referral hospital, Ethiopia. BMC Res Notes. 2014;7:838.

79. Abera B, Adem Y, Yimer M, Mulu W, Zenebe Y, Mekonnen Z. Community seroprevalence of hepatitis $B, C$ and human immunodeficiency virus in adult population in gojjam zones, Northwest Ethiopia. Virol J. 2017;14:21.
80. Abate M, Wolde T. Seroprevalence of human immunodeficiency virus, hepatitis $B$ virus, hepatitis $C$ virus, and syphilis among blood donors at Jigjiga blood Bank, eastern Ethiopia. Ethiop J Health Sci. 2016;26:153-60.

81. Mezgebo TA, Niguse S, Kahsay AG, Hailekiros H, Berhe N, Dejene TA. Hepatitis $B$ virus infection and associated risk factors among pregnant women attending antenatal care in health facilities of Tigray, northern Ethiopia. J Med Virol. 2018;90:503-9.

82. Wondimeneh $\mathrm{Y}$, Alem M, Asfaw F, Belyhun Y. HBV and HCV seroprevalence and their correlation with CD4 cells and liver enzymes among HIV positive individuals at University of Gondar Teaching Hospital, Northwest Ethiopia. Virol J. 2013;10:171.

83. Desalegn Z, Mihret A, Beyene H, Yilma M, Seid Y, Tamiru W, et al. Survey of hepatitis $B$ virus infection and risk factors among pregnant women at public hospital in Ethiopia. Int J Biomed Res. 2016;7:450-6.

84. Desalegn Z, Selassie SG. Prevalence of hepatitis B surface antigen (HBsAg) among health professionals in public hospitals in Addis Ababa, Ethiopia. Ethiop J Health Dev. 2013;27:72-9.

85. Kebede W, Abdissa A, Seid Y, Mekonnen Z. Seroprevalence and risk factors of hepatitis B, hepatitis $C$ and HIV infections among prisoners in Jimma town, Southwest Ethiopia. Asian Pacific J Tropical Dis. 2017;7:270-5.

86. Kabato AA, Weldearegay GM. Prevalence and associated risk factors of hepatitis $B$ and hepatitis C virus among volunteer blood donors in Arba Minch blood Bank SNNPR, Ethiopia. J Med Laboratory Diagnosis. 2016;7:20-7.

87. Betela B, Kemal F, Nigussu D. Prevalence of hepatitis B virus and related risk factors: a case study at Assela referral hospital, Oromia, Ethiopia. Int STD Res Reviews. 2018;7:1-7.

88. Jonas MM. Hepatitis B and pregnancy: an underestimated issue. Liver Int. 2009:29:133-9.

89. Pawlowska M, Pniewska A, Pilarczyk M, Kozielewicz D, Domagalski K. Prophylaxis of vertical HBV infection. Expert Opin Drug Saf. 2016;15:1361-8.

90. Alter MJ. Epidemiology of hepatitis B in Europe and worldwide. J Hepatol. 2003;39:64-9.

91. Hou J, Liu Z, Gu F. Epidemiology and prevention of hepatitis B virus infection. Int J Med Sci. 2005;2:50-7.

92. Leroi C, Adam P, Khamduang W, Kawilapat S, Ngo-Giang-Huong N, Ongwandee $\mathrm{S}$, et al. Prevalence of chronic hepatitis B virus infection in Thailand: a systematic review and meta-analysis. Int J Infect Dis. 2016;51:36-43.

93. Schweitzer A, Horn J, Mikolajczyk RT, Krause G, Ott JJ. Estimations of worldwide prevalence of chronic hepatitis $B$ virus infection: a systematic review of data published between 1965 and 2013. Lancet. 2015;386:1546-55.

94. Mohammadi Z, Keshtkar A, Eghtesad S, Jeddian A, Pourfatholah AA, Maghsudlu $\mathrm{M}$, et al. Epidemiological profile of hepatitis B virus infection in Iran in the past 25 years; a systematic review and meta-analysis of general population studies. Middle East J Digestive Dis. 2016;8:5-18.

95. Badawi MM, Atif MS, Mustafa YY. Systematic review and meta-analysis of HIV, HBV and HCV infection prevalence in Sudan. Virol J. 2018;15:148.

96. Bigna JJ, Amougou MA, Asangbeh SL, Kenne AM, Noumegni SRN, NgoMalabo ET, et al. Seroprevalence of hepatitis B virus infection in Cameroon: a systematic review and meta-analysis. BMJ Open. 2017;7:e015298.

97. Ofori-Asenso R, Agyeman AA. Hepatitis B in Ghana: a systematic review \& meta-analysis of prevalence studies (1995-2015). BMC Infect Dis. 2016;16:130

98. Musa BM, Bussell S, Borodo MM, Samaila AA, Femi OL. Prevalence of hepatitis B virus infection in Nigeria, 2000-2013: A systematic review and meta-analysis. Niger J Clin Pract. 2015, 18:163-72.

99. Lingani M, Akita T, Ouoba S, Sanou AM, Sugiyama A, Tarnagda Z, et al. High prevalence of hepatitis B infections in Burkina Faso (1996-2017): a systematic review with meta-analysis of epidemiological studies. BMC Public Health. 2018;18:551.

100. Hassan-Kadle MA, Osman MS, Ogurtsov PP. Epidemiology of viral hepatitis in Somalia: systematic review and meta-analysis study. World J Gastroenterol. 2018;24:3927.

101. Babanejad M, Izadi N, Najafi F, Alavian SM. The HBsAg prevalence among blood donors from eastern Mediterranean and middle eastern countries: a systematic review and meta-analysis. Hepat Mon. 2016;16:e35664.

102. Rajendiran S, Gopalan U, Jayakumar K. Seroprevalence of hepatitis B infection among pregnant women in South India. Int J Reproduct Contraception Obstet Gynecol. 2017;6:249-51.

103. Moghaddasifar I, Lankarani KB, Moosazadeh M, Afshari M, Malary M. Prevalence of hepatitis $B$ virus infection among pregnant women in Iran: a systematic review and meta-analysis. Iran J Cancer Prevention. 2016;9:e3703. 
104. Badfar G, Shohani M, Nasirkandy MP, Mansouri A, Abangah G, Rahmati S, et al. Epidemiology of hepatitis B in pregnant Iranian women: a systematic review and meta-analysis. Arch Virol. 2018;163:319-30.

105. Agyeman AA, Ofori-Asenso R. Prevalence of HIV and hepatitis B coinfection in Ghana: a systematic review and meta-analysis. AIDS Res Ther. 2016;13:23.

\section{Publisher's Note}

Springer Nature remains neutral with regard to jurisdictional claims in published maps and institutional affiliations.

Ready to submit your research? Choose BMC and benefit from:

- fast, convenient online submission

- thorough peer review by experienced researchers in your field

- rapid publication on acceptance

- support for research data, including large and complex data types

- gold Open Access which fosters wider collaboration and increased citations

- maximum visibility for your research: over $100 \mathrm{M}$ website views per year

At BMC, research is always in progress.

Learn more biomedcentral.com/submissions 